\title{
A STUDY OF STUDENTS' PERSPECTIVES ON THE ADOPTION OF LMS AT UNIVERSITY OF KELANIYA.
}

\author{
Seiyathu Mohammathu Murshitha \\ Department of Management and Information Technology, South Eastern University of Sri Lanka \\ murshitha@seu.ac.lk
}

\author{
A.P. Ruwan Wickramarachchi \\ Department of Industrial Management, University of Kelaniya \\ ruwan@kln.ac.lk
}

\begin{abstract}
In the knowledge era, the adoption of Learning Management System (LMS) has become a requirement at Universities as it is enhancing the teaching and learning environment. Although the success of LMS adoption in Universities can be initiated by lecturer acceptance and use, it survives in the long run because of students' continuous acceptance and use. The objective of this study is to study students' perspectives on the adoption of LMS in blended learning environment. A survey is conducted among 50 undergraduate students who use LMS extensively at the Department of Industrial Management, University of Kelaniya in order to fulfill the objective. The conduct of this study involves quantitative approach. The result of the study indicates students' perspectives in terms of students' attitude towards LMS, self efficiency, experience and interaction with lecturers and other classmates play a significant role in determining students' LMS adoption.
\end{abstract}

Keywords: Blended learning, E-learning, and Learning Management System,

\section{Introduction}

The use of Information Communication Technology (ICT) is a vital prerequisite for the development of a knowledge-based economy. Universities are undergoing paradigmatic shifts as they make greater use of information and communications technologies. This has resulted in the use and adoption of e-learning, which has appeared as an essential tool to impart knowledge in the university as well as corporate sectors.

E-learning systems are adopted by some educational and technical training institutions to support distance learning (pure exclusive e-learning), whilst others use e-learning system to supplement more traditional ways of teaching (blended learning). For distance learning, e-learning systems can be fully used to build a virtual learning environment wherein all coursework is conducted exclusively online (Rainer et al., 2007). On the other hand, blended learning environment integrates instructional delivery in a face-to-face context with online learning, either synchronously or asynchronously (Gribbins et al., 2007). Thus, blended learning is defined as a combination (blend) of e-learning and face-to-face classroom learning environments (Graham, 2006; Wu and Hwang, 2010).

Among the e-learning tools on the market, LMSs are viewed as the most basic and reliable e-learning tool in blended learning environments, and they are often the starting point of any Web-based learning program (Kakasevski et al., 2008). Examples of LMS are Blackboard, WebCT, eCollege, Moodle, Desire2Learn, and ANGEL etc. An LMS not only provides academic institutions with efficient means to train and teach individuals, but also enables them to efficiently codify and share their academic knowledge (Al Busaidi, 2012). 
The usage of the LMS has become a requirement at Universities. Most of the Universities have developed their own LMS portal for the use of their own lecturers and students and expect lecturers and students to use these technologies for teaching and learning in an effective way. Although LMS survives via lecturers' and students' use, the adoption of LMS is initiated by lecturers' acceptance and use, which in turns initiates and promotes students' utilization of LMS in classes. As well as learners' continuous acceptance and use is significant for the success of LMS deployment. Thus examining the success factors of LMS deployment is essential for its continuous use. This study investigates the students' perspectives on the adoption of LMS in blended learning environment.

\section{Review of Literature}

Tertiary education, to be effective must connect students as dynamic members in their learning. Attaining this effectiveness indicates providing students' opportunities for interaction in means that can encourage modification and improvement in the student's formation or creation of knowledge. Tertiary education intends to persuade students to develop into independent enduring learners, proficient in problem solving and analytical thinking, and to shift them from being reactive receivers of information and knowledge to being proactive, eager learners and information inventors. In addition, tertiary education is aimed at constructing significant learning affiliations between students and teachers, and students and their peers. It involves persuading teamwork in learning as well as alliance in learning; the proper use of technology for teaching recommends grand chances for the encouragement of inventive and collaborative elearning atmospheres.

University students are becoming more diverse and demand for e-learning based courses is increasing (Papp, 2000; Volery and Lord, 2000). Students need to have time management, discipline, and computer skills in order to be successful in the e-learning era (Selim, 2007). Student earlier IT familiarity with computer and attitude towards e-learning is vital to e-learning accomplishment. A number of students' perspectives influence students' adoption of LMS.

Al-Busaidi (2012) concluded that learners' characteristics such as computer anxiety, technology experience and personal innovativeness are significant factors for learners' perceived ease of use of LMS, whereas technology experience is a significant factor for its actual use. Guo and Stevens, (2011) investigated the factors influencing perceived usefulness of wikis for group collaborative learning by first year students. The study found that wiki use was influenced by the student's prior or expertise with wikis, with their perceived usefulness of wikis and the ease of access to the wikis. The students' overall attitude towards wikis was largely influenced by the extent to which they saw wikis as helping with their assignment work, and their intension to use wikis in the future was driven by their perception of wiki's usefulness.

Ayub et al., (2010) identified students' technology competencies and attitudes toward the usage of LMS as the factors that influence students use of LMS in teaching and learning. Al-Busaidi (2009) examined several learners' characteristics in terms of self efficacy, attitude toward e-learning, e-learning experience, computer anxiety and personal innovativeness. These characteristics influence learners' acceptance of LMS.

According to Ozkan et al., (2009), learner perspectives includes learner attitude towards LMS, learner's computer anxiety, self efficiency, enjoyable experience and interaction with other students and teacher, and these factors influence students' adoption of LMS.

This study examines students' perspectives in terms of attitude towards LMS, computer antianxiety, self efficiency, experience and 
interaction with lecturers and other students and these factors influence the students' LMS adoption (see Figure 1)

\section{Research Framework}

The framework was conceptualized based on the work of Al- Busaidi (2012), Al- Busaidi (2009), Abbad et al., (2009), Sun et al., (2008), Ozkan et al., (2008), Wan et al., (2007), Pituch and Lee (2006), Arbaugh and Duray, (2002), Arbaugh, (2000), Wang and Newlin, (2002), Piccoli et al., (2001), Webster and Hackley (1997), and Sumner and Hostetler (1999).

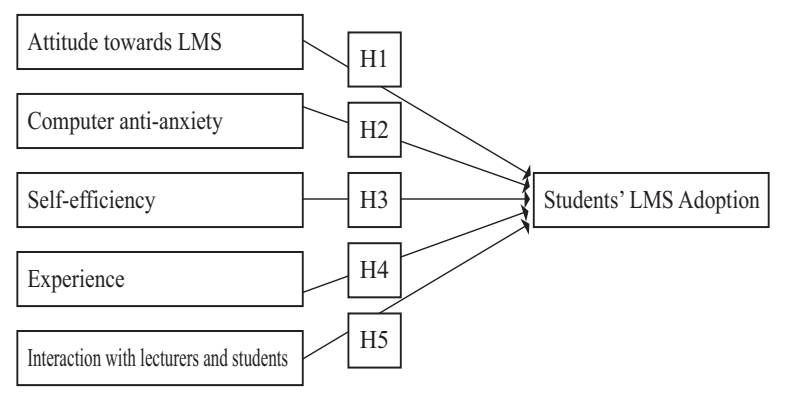

Figure 1 Research Framework

Students' attitude towards LMS: The definition of student attitude is students' "impression of participating in e-Learning activities through computer usage" (Sun et al.,2008). Students' attitude towards LMS is an important factor for their acceptance of LMS. According to Ozkan et al., (2008) learner attitudes toward computers will positively influence perceived e-learner satisfaction from LMS. Much research indicates that learner attitude towards computers or IT is an important factor in e-Learning satisfaction (Arbaugh, 2002; Arbaugh and Duray, 2002; Hong, 2002; Piccoli et al., 2001). A more positive attitude toward IT, for example, when students are not afraid of the complexity of using computers, will result in more satisfied and effective learners in an eLearning environment (Piccoli et al., 2001).

Computer anti-anxiety: Computer anxiety can be a critical factor for learners' acceptance of LMS. Users' anxiety is different from attitude which represents beliefs and feelings toward computers (Heissen et al., 1987). Computer anxiety is defined as the fear or apprehension felt by individuals when they used computers, or when they considered the possibility of computer utilization (Simonson et al., 1987, p. 238). Thus, computer anxiety can negatively impact learners' acceptance and use of LMS. Several empirical studies found a significant negative effect of users' computer anxiety on satisfaction of elearning (Sun et al., 2008), and usage of LMS (Al-Busaidi, 2009). A fear of computers will negatively impact the e-learning environment and, consequently, the user's perceived satisfaction (Piccoli et al., 2001). Learners with high computer anxiety will probably not accept and use LMS and will not be satisfied with it. They may consider it difficult and not useful.

Self efficiency: Computer self-efficacy refers to self-assessment of the ability to apply computer skills to accomplish tasks (Compeau et al., 1995). Bandura (1986, p. 391) defined selfefficacy as people's judgments of their capabilities to organize and execute courses of action required to attain designated types of performances. The higher the learners' computer self-efficacy, the more likely they are to use to become satisfied with it. In the e-learning context, self-efficacy is interpreted as a student's self-confidence in his or her ability to perform certain learning tasks using a learning management system (LMS). A student who has a strong sense of his capability in dealing with an LMS may have a more positive perception of its ease of use and usefulness and is likely to be more willing to accept and use the system. Wang and Newlin (2002), from research on 122 students, conclude that students with higher selfefficacy are more inclined to adopt networkbased learning and earn significantly better final grades.

Experience: Learners' experience with the use of technology plays a role in the effective use of technology. An individual's experience with the use of technology is the individual's exposure to the technology (e.g., LMS) and the skills and 
abilities that he or she gains through using a technology (Thompson et al., 2006). Learners' technology experience has a major impact on learning processes and, consequently, learning outcomes (Wan et al., 2007). Learners' experience is important for learners' perceived ease of use and perceived usefulness of LMS (Pituch and Lee, 2006). In addition, the current level of computer skills and extent of use of computing skills in teaching are important for acceptance of ICT in education (Sumner and Hostetler, 1999). The more technology experience a learner has, the more accustomed the learner will be to ICT in education and will perceive it as easy and useful and use it. Moreover, long-term technology experience indicates that learners are satisfied with the technology.

Interaction with lecturers and other students: The key elements of learning processes are the interactions among students themselves, the interactions between faculty and students, and the collaboration in learning that results from these interactions. Interaction in an e-learning environment not only involves learners with the instructor, but also learners with other learners (Moore, 1989). A major source of developments in e-learning has come via technologies that promote increased learner interaction. Interactions can be either synchronous or asynchronous (Abbad et al., 2009). Thus interaction with learners and lecturers in an elearning environment is a very important factor for learners' acceptance, use, and satisfaction with LMS in blended learning. The frequency, quality, and promptness of interaction in an elearning environment might affect the learner's satisfaction and learning success (Sun et al., 2008). Hence, classmates' interaction through the LMS enhances the learner's perception of usefulness of LMS stimulates learner use and satisfaction.

Based on the preceding discussion, the following hypotheses were formulated
H1: Students' attitude towards LMS is significantly related with their LMS adoption.

H2: Students' computer anti-anxiety is significantly related with their LMS adoption

H3: Student' self efficiency is significantly related with their LMS adoption

H4: Students' experience in using the LMS is significantly related with their LMS adoption

H5: Students' interaction with lecturers and other classmates is significantly related with their LMS adoption

\section{Research Methodology}

The conduct of this study is using quantitative approach. Department of Industrial Management, University of Kelaniya is involved in the study. Findings of the study are then used to test the formulated hypotheses. In order to test hypotheses, self-administered questionnaire is disseminated to the LMS adopters. A stratified sampling technique is adopted in order to assure that respondents are well responded. A total of 50 questionnaires are distributed and all of them are returned and usable. Table 1 summarizes the demographic profile and descriptive statistics of the respondents.

Table 1:

Demographic profile and descriptive statistics of surveyed students

\begin{tabular}{|l|c|c|}
\hline Item & Frequency & Percentage \\
\hline Gender & 19 & 38 \\
Male & 31 & 62 \\
Female & & \\
\hline Age or Level & 24 & 48 \\
20-22 (Level 2) & 26 & 52 \\
23-25 (Level 3) & & \\
\hline PC ownership & 42 & 84 \\
Yes & 08 & 16 \\
No & & \\
\hline Laptop ownership & 47 & 94 \\
Yes & 03 & 06 \\
No & 15 & 30 \\
\hline Often of LMS use & 35 & 70 \\
Regular & & \\
Just-to download & & \\
\hline
\end{tabular}


A survey instrument is developed in order to specify the students' perspective factors within each category. The students' attitude towards LMS constructs are self developed based on the work of Venkatesh and Davis (1996) and Rogers' (2003). To capture students' computer anti anxiety the measure is self developed based on the work of Al- Busaidi $(2009,2012)$. Students' self efficiency construct is self developed based on the work of Wang and Newlin (2002). Students' experience measure is self developed based on the work of Ozkan et al., (2008). To measure students' interaction with lecturers and other classmates, the construct is adopted from the work of Ozkan et al., (2008). All items used a five-point Likert-type scale of potential responses: strongly agree, agree, neutral, disagree, and strongly disagree. Statistical software package SPSS version 16.0 is used to analyze the data.

The study employed correlation and regression analysis. According to Alreck and Settle (1995), when the objective of the study is to test the degree and significance between two continuous variables from interval or ratio scales, the appropriate techniques is either correlation or regression analysis. According to Bryman and Cramer, (2001) Correlation entails the provision of a yardstick whereby the intensity of strengths of a relationship can be measured. However correlation analysis gauges only the degree to which two variables are related or move together but there is no assumption that one is causing or affecting the other (Alreck and Settle, 1995). Therefore, to measure the degree and direction of influence the independent variable on the dependant variable, the regression analysis is also applied in this study.

\section{Findings and Discussion}

Students' perspectives that are examined in this study consist of students' attitude towards LMS, computer anti-anxiety, self efficiency, experience and interaction with lecturers and other students. As shown in Table 2, the correlation analysis between the aforementioned variables (except students' computer anti-anxiety) against students'
LMS adoption produced significant positive correlations. Finally regression analysis (see Table 3) using the enter method is also executed separately between students' perspective variables and their LMS adoption.

Table 2:

Correlation matrix between students' perspectives and students' adoption of LMS

\begin{tabular}{|l|c|c|}
\hline Students' Perspectives & Correlation & P Value \\
\hline Attitude towards LMS & $0.681 * *$ & 0.000 \\
\hline Computer anti-anxiety & 0.227 & 0.113 \\
\hline Self efficiency & $0.329 *$ & 0.020 \\
\hline Experience & $0.652^{* *}$ & 0.000 \\
\hline $\begin{array}{l}\text { Interaction with learners } \\
\text { and students }\end{array}$ & $0.487 * *$ & 0.000 \\
\hline
\end{tabular}

Students' attitude towards LMS has significant positive relationship with their LMS adoption $(\mathrm{r}=$ $0.681, \mathrm{p}=0.000<$ alpha $=0.05)$. This indicates that, students' attitude towards LMS positively affect their adoption of LMS. Further, based on the regression analysis (see Table 3), it is discovered that students' attitude towards LMS solely explains $46.4 \%$ variation in their LMS adoption i.e. $\mathrm{R}^{2}=0.464$, with $\mathrm{F}=41.474$, and $\mathrm{p}$ $=0.000$. Therefore $\mathrm{H} 1$ is well supported and further supports previous studies by Piccoli et al., (2001) Arbaugh, (2000), Arbaugh and Duray, (2002), Hong, (2002), and Ozkan et al., (2008).

Table 3:

Summary of regression analysis between students' perspective variables and their adoption of LMS

\begin{tabular}{|l|c|c|c|c|c|}
\hline $\begin{array}{l}\text { Students' } \\
\text { Perspectives }\end{array}$ & $\mathbf{B}$ & $\mathbf{R}^{\mathbf{2}}$ & $\begin{array}{l}\text { Adjus } \\
\text { ted R }\end{array}$ & $\mathbf{F}$ & $\mathbf{P}$ \\
\hline $\begin{array}{l}\text { Attitude } \\
\text { towards } \\
\text { LMS }\end{array}$ & 0.785 & 0.464 & 0.452 & 41.474 & 0.000 \\
\hline $\begin{array}{l}\text { Computer } \\
\text { anti-anxiety }\end{array}$ & 0.187 & 0.051 & 0.032 & 2.601 & 0.113 \\
\hline $\begin{array}{l}\text { Self } \\
\text { efficiency }\end{array}$ & 0.283 & 0.108 & 0.089 & 5.809 & 0.020 \\
\hline Experience & 0.491 & 0.425 & 0.413 & 35.436 & 0.000 \\
\hline $\begin{array}{l}\text { Interaction } \\
\text { with learners } \\
\text { and students }\end{array}$ & 0.392 & 0.237 & 0.221 & 14.912 & 0.000 \\
\hline
\end{tabular}


Results of the correlation analysis unveiled that there exist positive correlation between students' computer anti-anxiety and their LMS adoption. The value of Pearson's $r=0.227, p=0.113$. Consequently, based on the regression analysis, it is noted that the value of $\mathrm{R}^{2}=0.051$ denoting that computer anti-anxiety explains $5 \%$ of the variation on LMS adoption (see Table 3). The finding also implied that the formulated hypothesis $\mathrm{H} 2$ is supported and further support previous studies by Heissen et al., 1987, Piccoli et al., 2001, Sun et al., 2008 and Al-Busaidi, 2009.

In the e-learning context, self-efficacy is interpreted as a student's self-confidence in his or her ability to perform certain learning tasks using a learning management system (LMS). This study at hands hypothesizes that self efficiency is significantly related to LMS adoption. Results of the correlation analysis (see Table 2) indicates that the value of Pearson's $r=$ $0.329, \mathrm{p}=0.020<$ alpha $=0.05$. This value suggests that correlation exists between students' self efficiency and their LMS adoption.

Further results of the regression analysis unveiled that the value of $\mathrm{R}^{2}=0.108$, with $\mathrm{F}$ $=5.809$ and $p=0.020$ (see Table 3 ), thus students' self efficiency explains $10.8 \%$ of the variation in LMS adoption and evidently support the hypothesis H3. Apparently, positive moderate relationship between self efficiency and LMS adoption also confirmed. Hence, support and strengthen findings by Wang and Newlin (2002).

As shown in Table 2, result of the correlation analysis between experience and LMS adoption indicates strong positive relationship. The value of Pearson's $r=0.652$. Based on the results of the regression analysis as displayed in Table 3, students' experience explains $42.5 \%$ variations in their LMS adoption with $F=35.436$ and $p$ $=0.000$. This finding entails that $\mathrm{H} 4$ is substantially supported and thus consistent with the findings of Sumner and Hostetler (1999), Pituch and Lee (2006) and Wan et al. (2007).
Correlation analysis between students' interaction with lecturers and other students and students' LMS adoption yields Pearson's $r=0.487$, and hence it can be confirmed that positive significant relationship exists between the aforesaid two variables. Results of regression analysis indicate that the interaction with lecturers and students explains $23.7 \%$ variation in LMS adoption with $\mathrm{F}=14.912$ and $\mathrm{p}=0.000$. Nevertheless, the result has further strengthened finding by Sun et al., (2008).

\section{Conclusion}

In an LMS adopting environment, especially in the context of Department of Industrial Management, university of Kelaniya, it is not really known on the status of students' perspectives on their LMS adoption. In Sri Lankan context, perspectives such as students' attitude towards LMS, computer antianxiety, self efficiency, experience and interaction with lecturers and other classmates remain unknown until the venturing of this study. Students' perspectives including the aforesaid factors play a significant role in determining their LMS adoption. Results and findings of this study have provided empirical evidence regarding the important aspect of students' perspectives that would significantly contribute towards students' LMS adoption.

Universities should support LMS deployment through improving learners' perspectives such as attitude towards LMS, experience, interaction with lecturers and other students, self efficiency and computer anti-anxiety

Students' attitude is the students' impression of participating in e-learning activities through computer usage, thus using LMS environment. Respondents of this study have agreed that their attitude towards LMS is encouraging and gladdening, and positively inclined towards creating an environment for LMS adoption. This is because all most all the students perceive that using the LMS would enhance their learning task in numerous ways. This is consistent with 
Technology Acceptance Model or TAM (Davis, 1989; Venkatesh and Davis, 1996). According to this model, beliefs that a new application of technology is useful and easy to use influence the users' attitudes toward the technology and thereby their decision to use the technology. This study has provided empirical evident in supporting TAM that perceived usefulness is a driver of individuals' LMS adoption via influencing their attitude. Among the five students' perspective dimensions, this dimension scores the highest rating from respondents. Without doubt, Students' attitude toward LMS explains about $46.4 \%$ of the variation of their LMS adoption.

Computer anti-anxiety is different from attitude which represents beliefs and feelings toward computers. Generally respondents have agreed that computer anti-anxiety is found to be positively correlated to LMS adoption. This is because; the students do not feel any difficulties in using the LMS. Thus the system quality features such as easy interface, easy structure, easy navigation, easy access etc. which make them not to feel any difficulties and to use LMS for their learning task. Indeed, findings of this study have certainly confirmed that computer anti-anxiety is found to be positively correlated to LMS adoption.

In this study, students' self efficiency is found to be strong predictor to their LMS adoption. This is, as the respondents are confident enough to use all the contents of LMS; and have a more positive perception of its ease of use and usefulness and is likely to be more willing to accept and use the LMS.

In term of experience, the respondents of this study indicates positive stance and their experience solely explains $42.5 \%$ variations on LMS adoption. The fact behind this is that $52 \%$ of respondents are using LMS for three years and $48 \%$ of respondents are using LMS for two years. Thus, all respondent have enough experience with LMS and enjoy using LMS for their learning purposes.
In term of interaction with lecturers and other students, respondents of this study indicate positive stance and these motivating them in adopting the LMS. This is because the respondents of this study believe that the LMS makes the communication easier with lecturers and classmates. Hence, students' interaction through the LMS enhances the learner's perception of easiness and usefulness of LMS stimulates learner use and satisfaction.

This study confirmes some findings of previous studies of Al- Busaidi (2012), Al- Busaidi (2009), Abbad et al., (2009), Sun et al., (2008), Ozkan et al., (2008), Wan et al., (2007), Pituch and Lee (2006), Arbaugh, (2002), Arbaugh et al., (2002), Wang and Newlin, (2002), Piccoli et al., (2001), Webster and Hackley (1997) and Sumner and Hostetler (1999).

The above mentioned studies had been done in foreign countries thus in the Middle East, and in Malaysia and Oman and such knowledge is lacking in Sri Lankan context. Hence, this study has provided valuable insights for students and universities in Sri Lankan perspectives.

\section{Limitations and Future Research}

This study has limitations. First, the sample is collected from the Department of Industrial Management, university of Kelaniya, more researches can be conducted at several department, and in different universities to evaluate the findings that would be appropriate to generalize the findings. Second future research might also examine the other critical factors (i.e. lecturers' performance, LMS characteristics, and university support) influencing the success of universities' LMS adoption in detail. Also, the study assesses LMS adoption from students' perspective and further research may evaluate it from lecturers' perspective. 


\section{References}

Abbad, M.M., Morris, D. and Nahlik, C. (2009), "Factors Affecting Student Adoption of ELearning Systems in Jordan" International Review of Research in Open and Distance Learning, Vol. 10, Number 2. ISSN: 1492-3831

Al-Busaidi, K.A. (2009), "The Impact of Learning Management System Characteristics and User Characteristics on the Acceptance of ELearning" International Journal of Global Management Studies Vol. 1, No. 2, pp. 75-91.

Al-Busaidi, K.A. (2012), "Learners' Perspective on Critical Factors to LMS Success in Blended Learning: An Empirical Investigation." Communications of the Association for Information Systems: Vol. 30, Article2.

Alreck, P.L. and Settle, R.B. (1995), "The survey research handbook." $2^{\text {nd }}$ edition. Chicaco: Irwin.

Arbaugh, J. B., and Duray, R. (2002) ,"Technological and structural characteristics, student learning and satisfaction with webbased courses - An exploratory study of two on-line MBA programs." Management Learning, Vol. 33, No. 3, pp. 331-347.

Arbaugh, J.B. (2000), "Virtual Classroom Characteristics and Student Satisfaction with Internet-Based MBA Courses" Journal of Management Education Vol. 24, No. 1, pp. 32-54.

Ayub, A.F.M., Tarmizi R.A., Jaafar, W M.W., Ali, W.Z.W. and Luan, W.S. (2010), "Factors influencing students' use of a LMS portal: Perspective from Higher education students." International Journal of Education and Information Technology. Issue 2, Volume 4, 2010.

Bryman, A. and Cramer, D. (2001), "Quantitative data analysis with SPSS Release 10 for Windows: A Guide for Social Scientists. New York: Routledge.

Compeau, R., Deborah, A., Higgins, A. and Christopher. (1995), "Computer Self-Efficacy: Development of a Measure and Initial Test" MIS Quarterly, Vol. 19 No. 2, pp. 189-211.
Graham, C.R. (2006), "Chapter 1: Blended Learning System: Definition, Current Trends, Future Directions" in Bonk, C.J. and C.R. Graham (eds.) Handbook of Blended Learning, San Francisco, CA: Pfeiffer.

Gribbins, M.L., Hadidi, R., Urbaczewski, A. and Vician, C. (2007), "Technology-Enhanced Learning in Blended Learning Environments: A Report on Standard Practices" Communications of the Association for Information Systems (20) Article 46, pp. 741-759.

Guo Z., and Stevens, K.J. (2011), "Factors influencing perceived usefulness of wikis for group collaborative learning by first year students" Australasian Journal of Educational Technology Vol. 27, No. 2, pp. 221-242.

Heissen, R.K., Jr., Glass, C.R., \& Knight, L.A. (1987), Assessing computer anxiety: development and validation of the computer attitude rating scale. Computer in Human Behavior, Vol. 3, No. 1, pp. 49-59.

Hong, K.S. (2002), "Relationships between students' and instructional variables with satisfaction and learning from a Web-based course", Internet and Higher Education, Vol. 5, pp. $267-281$

Kakasevski, M., Sime A., and Slavcho C. (2008), "Evaluating Usability in Learning Management System Moodle." Proceedings of the ITI 2008 $30^{\text {th }}$ International conference on IT interfaces, June 23- 26, Cavtat, Croatia.

Moore, M.G. (1989), "Three types of interaction", The American Journal of Distance Education Vol. 3, No. 2, pp. 1-6.

Ozkan S., Koseler R., Baykal N. (2009), "Evaluating Learning Management System: Hexagonal e-learning Assessment Model." Transforming Government: People, Process and Policy, Vol. 3 No. 2, pp. 111-130, Emerald Group Publishing Limited

Papp, R. (2000), "Critical success factors for distance learning" Paper presented at the Americas Conference on Information Systems, Long Beach, CA, USA. 
Piccoli, G., Ahmad, R., \& Ives, B. (2001), "Webbased virtual learning environments: a research framework and a preliminary assessment of effectiveness in basic IT skill training." MIS Quarterly, Vol. 25, No. 4, pp. 401-426.

Pituch, K. and Y. Lee (2006), "The Influence of System Characteristics on E-Learning Use" Computers \& Education Vol. 47, No. 2, pp. 222-244.

Rainer, R.K., E. Turban, and R.E. Potter (2007), "Introduction to Information Systems: Supporting and Transforming Business" Hoboken, NJ.: John Wiley \& Sons, Inc.

Rogers, M. E. (2003), Diffusion of innovations (5th ed.). New York: The Free Press.

Selim, H.M. (2007), "Critical Success Factors for e-learning acceptance: confirmatory factor models." Computers \& Education 49 (2007) pp. 369-413.

Sumner, M. and D. Hostetler (1999) "Factors Influencing the Adoption of Technology in Teaching", The Journal of Computer Information Systems (40)1, p. 81.

Sun, P.C., Tsai, R.S., Finger, G., Chen, Y.-Y. and Yeh, D. (2008), "What drives a successful elearning? An empirical investigation of the critical factors influencing learner satisfaction", Computers \& Education, Vol. 50 No. 4, pp. 1183-1202.

Thompson, R., Compeau, R. Deborah, and Higgins, C. (2006), "Intentions to Use Information Technologies: An Integrative Model" Journal of Organizational and End User Computing, Vol. 8, No. 3, pp. 25-47.

Venkatesh, V. and Davis, F. D. (2000), “A theoretical extension of technology acceptance model: Four longitudinal field studies" Management Science, Vol. 46, pp. 186-204.

Volery, T., and Lord, D. (2000), "Critical success factors in online education." The International Journal of Educational Management, Vol. 14, No. 5, pp. 216-223.
Wan, Z., Y. Fang, and H. Neufeld (2007), “The Role of Information Technology in Technology-Mediated Learning: A Review of the Past for the Future", Journal of Information Systems Education Vol. 18, No. 2, pp. 183-192.

Wang, A.Y. and Newlin, M. H. (2002) "Predictors of web student performance: The role of selfefficacy and reasons for taking an on-line class" Computers in Human Behavior, Vol. 18 No. 2, pp. 151-163.

Webster, J. and Hackley, P. (1997), "Teaching Effectiveness in Technology-Mediated Distance Learning." Academy of Management Journal Vol. 40 No. 6, pp. 1282-1309.

Wu, W.C, Hwang, L.Y. (2010), "The Effectiveness of e-Learning for Blended Courses in Colleges" International Journal of Electronic Business Management, Vol. 8, No. 4, pp. 312-322 (2010) 